Article available at nttp://WwW.parasite-journal.org or nttp://dx.dol.org/10.1051/parasite/1996033283

\title{
THE EXPULSION OF ECHINOSTOMA TRIVOLVIS : SUPPRESSIVE EFFECTS OF DEXAMETHASONE ON GOBLET CELL HYPERPLASIA AND WORM REJECTION IN C3H/HEN MICE
}

\author{
FUJINO T.*, ICHIKAWA H.**, FRIED B.**** \& FUKUDA K.*****
}

\section{Summary :}

$\mathrm{C} 3 \mathrm{H} / \mathrm{HeN}$ mice were infected with Echinostoma trivolvis metacercariae on day $\mathrm{O}$, given intramuscular injections of dexamethasone daily for 5 or 7 days, and necropsied on days 5 , $8,12,15,20$ and $30 \mathrm{p}$. i. Controls consisted of mice that were infected with echinostomes, but were not treated with dexamethasone. Dexamethasone treatment caused a delay in worm expulsion from the small intestine of the hosts, and the increase in goblet cell numbers that occurred in untreated mice was markedly delayed in the treated mice. Mast cell number in the small intestine increased rapidly from just after day 5 p. i. and reached a peak on day 15 p. i. in both dexamethasone-treated and control mice, although the increase in cell numbers was delayed slightly in the dexamethasone-treated mice. The eosinophil number in the small intestine of dexamethasone-treated mice was suppressed until 8 days p. i. and then increased reaching a peak on day 12 p. i., although the number was about one half that of the control. As determined on day 12 p. i., the mean body area of worms from dexamethasone-treated animals was significantly greater than that of the controls. Histological examination of the small intestine showed that the goblet and Paneth cell hyperplasia seen in mice infected with $E$. trivolvis was suppressed by dexamethasone-treatment. Transmission electron microscopy revealed no marked ultrastructural differences in the small intestine of the dexamethasone-treated and control mice except that the former had an increased number of intracristal granules in mitochondria, an increase in vesicles in the apical epithelial cells and an increase in amorphous bodies and autophagic vacuoles in the Paneth cells. These results indicate that dexamethasone treatment delayed the expulsion of E. trivolvis from the small intestine of the host mouse in association with the suppression of goblet cell hyperplasia and increase in the number of mast cells and eosinophils.

KEY WORDS : Echinostoma trivolvis, dexamethasone, goblet cell hyperplasia worm rejection, $\mathrm{C} 3 \mathrm{H} / \mathrm{HeN}$ mice.

\section{INTRODUCTION}

$\mathrm{R}$ ejection of Echinostoma trivolvis (referred to as E. revolutum, see Christensen et al., 1990) from the intestine of ICR mice (Hosier \& Fried, 1986;

\footnotetext{
* Department of Parasitology, Faculty of Medicine, Kyushu University, Fukuoka 812-82, Japan. Fax: 092-632-6402 - Tel. : 092-641-1151. ** Department of Medical Zoology, Kanazawa Medical University, Ishikawa 920-02, Japan

**** Department of Biology, Lafayette College, Easton, PA 18042, USA

**** Center for Laboratory Animal Science, National Defense Medical College, 359 Tokorozawa, Japan.
}

Résumé : L'EXPULSION DE ECHINOSTOMA TRIVOLVIS : EFFETS SUPPRESSEURS DE LA DEXAMÉTHASONE SUR L'HYPERPLASIE DES CELLULES CALICIFORMES ET L'ÉLIMINATION DES VERS CHEZ LA SOURIS C3H/HeN Des souris $\mathrm{C} 3 \mathrm{H} / \mathrm{HeN}$ ont été infectées à $\mathrm{JO}$ avec des métacercaires d'Echinostoma trivolvis, ont reçu quotidiennement de la dexaméthasone en intra-musculaire pendant 5 à 7 jours et ont été nécropsiées à J5, J8, J12, J15, J20 et J30. Des souris témoins ont été infectées par les échinostomes, mais n'ont pas été traitées par la dexaméthasone. Le traitement par la dexaméthasone a provoqué un retard dans l'expulsion intestinale des vers par l'hôte, et l'augmentation du nombre des cellules caliciformes observé chez les souris non traitées a été nettement retardée chez les souris traitées. Le nombre de mastocytes intestinaux a rapidement augmenté juste après 15 et atteint un pic à 175 chez les souris traitées comme chez les témoins, bien que l'augmentation du nombre de cellules ait été légèrement retardée chez les souris traitées. Le nombre d'éosinophiles intestinaux des souris traitées était de zéro 8 jours après l'infection, puis a augmenté jusqu'à un pic à J12, mais égal à la moitié du pic observé chez les témoins. La masse corporelle moyenne des vers déterminée 12 jours après l'infection était significativement plus importante que celle des témoins. L'examen histologique du petit intestin a montré que I'hyperplasie des cellules caliciformes et des cellules de Paneth observée chez les souris infectées par E. trivolvis était supprimée par le traitement à la dexaméthasone. La microscopie électronique n'a pas révélé de différences ultrastructurales marquées dans le petit intestin des deux groupes, si ce n'est que celui des souris traitées comportait une augmentation du nombre des granules mitochondriaux, des vésicules des cellules épithéliales apicales, et une augmentation des corps amorphes et des vacuoles autophages dans les cellules de Paneth. Ces résultats indiquent qu'un traitement par la dexaméthasone retarde l'expulsion de $\mathrm{E}$. trivolvis par le petit intestin de la souris hôte, en association avec la suppression de l'hyperplasie des cellules caliciformes et de l'augmentation du nombre des mastocytes et des éosinophiles.

MOTS CLÉS : Echinostoma trivolvis, dexaméthasone, hyperplasie des cellules caliciformes, élimination des vers, souris $\mathrm{C} 3 \mathrm{H} / \mathrm{HeN}$.

Weinstein \& Fried, 1991) and BALB/c mice (Fujino et al., 1993) occurred within three and two weeks, respectively. Weinstein \& Fried (1991) and Fujino et al. (1993) proposed that the rapid expulsion of E. trivolvis may be associated mainly with an increased number of goblet cells, but not mast cells.

Immuno-suppressed animals have been used for infection with some helminths including the echinostome E. caproni (referred to as E. revolutum in Christensen et al., 1986) to observe changes in host immunity to the worms (Ogilvie, 1965; Christensen et al., 1986; McKay et al., 1990; Abe et al., 1994; Ishikawa, 1994; 
Ishikawa et al., 1994). Recently, McMaster et al. (1995) examined the effect of dexamethasone on the course of E. trivolvis and E. caproni infection in the small intestine of the golden hamster. Increased worm recovery, decreased total white blood cell counts, decreased relative spleen weights and lower worm dry weights occurred as a result of high doses of dexamethasone (McMaster et al., 1995)

The present study was designed to examine the effect of corticosteroid administration on the course of E. trivolvis infection in $\mathrm{C} 3 \mathrm{H}$ mice, especially in view of the suppressive effect of this steroid on goblet cell hyperplasia in the host intestines and on worm rejection.

\section{MATERIALS AND METHODS}

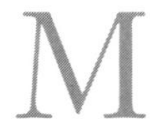
etacercarial cysts of Echinostoma trivolvis were obtained from the kidney and pericardial sac of laboratory-infected Biomphalaria glabrata snails. The strain of the worms was previously described by Fujino \& Fried (1993). A total of 84 outbred male $\mathrm{C} 3 \mathrm{H} / \mathrm{HeN}$ mice aged 6-8 weeks were obtained from the Laboratory of Animal Experiments of Kyushu University. Forty cysts were fed via a stomach tube to each mouse, and seven mice were killed by light anaesthesia with ether and cervical dislocation on days $5,8,12,15,20$ and 30 post-exposure. The mice were given intramuscular injections of dexamethasone (DEX) (Sigma) at $2 \mathrm{mg} / \mathrm{kg}$ per day for five or seven days after infection with the cysts. Six groups of untreated control mice, seven per group, were injected intramuscularly with physiological saline and were also killed on days 5, 8, 12, 15, 20 and 30 postexposure. The mice were starved for about $12 \mathrm{~h}$ before necropsy to avoid food residue in the intestine. The entire intestine was removed and opened longitudinally to determine the location of worms. The worms were counted and their distribution was recorded in the small intestine that was divided equally into anterior, middle and posterior region, and caecum and colon plus rectum.

For histological samples, a region of the small intestine, the middle jejunum to ileum, was excised and fixed for 2-6 h in either $10 \%$ neutral buffered formalin or Carnoy's fixative. Samples were dehydrated with an ethanol series and embedded in paraffin. Histological sections $5 \mu \mathrm{m}$, were stained with alcian blue $(\mathrm{pH} 2.5)$ periodic-acid Schiff (AB-PAS) for goblet cell mucins. Mucosal mast cells were stained with alcian blue (pH 0.3) and safranin. For eosinophil counts staining with Biebrich scarlet (Konwalinka et al., 1980) was done. All counts were expressed as the number of cells per villus-crypt unit (VCU) (Miller \& Jarrett, 1971). Where applicable Student's t-test was used to analyse differences between means and $p<0.05$ was considered significant. Transmission electron microscopy (TEM) followed the method of Fujino et al. (1993).

Semi-thin sections were cut and stained with toluidine blue $\mathrm{O}$ and examined by light microscopy. Ultrathin sections made from five to seven blocks were doublestained with uranyl acetate and lead acetate and viewed in a Hitachi H-500 electron microscope operating at $75 \mathrm{kV}$.

Body area measurements in $\mathrm{mm}^{2}$ (maximum width $\times$ length) were made on 29-50 worms on days 8 and 12 ; the worms were flattened moderately between two glass slides in $70 \%$ ethanol, stained with haematoxylin, dehydrated in an ethanol series, cleared in xylene and mounted in Permount (Fujino et al., 1993).

\section{RESULTS}

\section{INFECTIVITY AND DISTRIBUTION}

$\checkmark$ he infectivity and worm recovery data are presented in Table I. All untreated control mice were infected with the worms on days 5 and 8 p. i. By day 12 p. i., three of seven mice were infected, but none was infected beyond day 15 p. i. All of the DEX-treated mice were infected with E. trivolvis until day 15 p. i. Worm recoveries in the controls were 69.3 and $61.1 \%$ on days 5 and 8 p. i., respectively. The worm recovery dropped to $17.1 \%(p<0.005)$ on day 12 p. i. and fell markedly to zero by day 15 p. i. Worm recoveries in the DEX-treated mice were greater than $80 \%$ on days 5 and 8 p. i., were somewhat lower on days 12 and 15 p. i. (not significant), and then fell rapidly to zero by day $20 \mathrm{p}$. i.

In both the control and DEX-treated mice, most worms were in the middle part of the small intestine on day 5 p. i. Most worms were located in the posterior part of the small intestine by day $8 \mathrm{p}$. i. In the control mice, all worms were in the caecum or colon+rectum and none in the small intestine by day $12 \mathrm{p}$. i. In contrast, most worms from DEX-treated mice were in the middle and posterior part of the small intestine on day $12 \mathrm{p}$. i. and then were located in the posterior part of the small intestine and the caecum and colon+rectum by day 15 p. i.

\section{BODY AREA}

The body areas of E. trivolvis from both groups were almost the same on day 8 p. i. The body area of worms $\left(8.7 \pm 0.2 \mathrm{~mm}^{2}\right)$ from the DEX-treated mice increased markedly on day 12 p. i., and was more than 2.5 times that of the worms $\left(3.4 \pm 0.2 \mathrm{~mm}^{2}\right)$ from the control mice. Most of the worms recovered from the DEXtreated mice on day 12 p. i. were gravid and contained 


\begin{tabular}{|c|c|c|c|c|c|c|}
\hline \multirow{2}{*}{ Group } & \multirow{2}{*}{$\begin{array}{l}\text { Day post- } \\
\text { infection }\end{array}$} & \multirow{2}{*}{$\begin{array}{l}\text { No. of exposed } \\
\text { mice (infected) }\end{array}$} & \multirow{2}{*}{$\begin{array}{l}\text { Mean ( } \pm \text { S. E.) no. of } \\
\text { worms recovered }(\%)\end{array}$} & \multicolumn{3}{|c|}{ No. of worms located in the } \\
\hline & & & & $\begin{array}{l}\text { Small intestine } \\
\text { Totals (I II III) }\end{array}$ & Caecum & $\begin{array}{l}\text { Colon+ } \\
\text { Rectum }\end{array}$ \\
\hline \multicolumn{7}{|l|}{ Control } \\
\hline A & 5 & 7 (7) & $27.7 \pm 1.9(69.3)$ & $194\left(\begin{array}{lll}7 & 151 & 36\end{array}\right)$ & 0 & 0 \\
\hline B & 8 & $7(7)$ & $24.4 \pm 1.7(61.1)$ & $124(6 \quad 28 \quad 90)$ & 24 & 23 \\
\hline $\mathrm{C}$ & 12 & $7(3)$ & $6.9 \pm 3.3(17.1)$ & 0 & 28 & 20 \\
\hline $\mathrm{D}$ & 15 & $7(0)$ & 0 & 0 & 0 & 0 \\
\hline E & 20 & $7(0)$ & 0 & 0 & 0 & 0 \\
\hline $\mathrm{F}$ & 30 & $7(0)$ & 0 & 0 & 0 & 0 \\
\hline \multicolumn{7}{|l|}{ Treated } \\
\hline G & 5 & $7(7)$ & $32.1 \pm 3.4(80.4)^{*}$ & $225\left(\begin{array}{lll}4 & 146 & 75\end{array}\right)$ & 0 & 0 \\
\hline $\mathrm{H}$ & 8 & $7(7)$ & $32.6 \pm 1.7(81.4)^{* *}$ & $228\left(\begin{array}{lll}25 & 62 & 141\end{array}\right)$ & 0 & 0 \\
\hline I & 12 & $7(7)$ & $29.7 \pm 2.8(74.3)^{* *}$ & $199\left(\begin{array}{lll}19 & 101 & 79\end{array}\right)$ & 4 & 5 \\
\hline $\mathrm{J}$ & 15 & $7(7)$ & $24.3 \pm 2.4(60.7)$ & $72\left(\begin{array}{lll}0 & 14 & 58\end{array}\right)$ & 32 & 66 \\
\hline $\mathrm{K}$ & 20 & $7(0)$ & 0 & 0 & 0 & 0 \\
\hline $\mathrm{L}$ & 30 & $7(0)$ & 0 & 0 & 0 & 0 \\
\hline
\end{tabular}

Groups A-F of upper table are untreated controls, and groups G-L of lower table are dexamethasone-treated mice.

I : Anterior; II : Middle; III : Posterior; * not significant against untreated control; ${ }^{* *}$ significant against untreated control, $p<0.005$.

Table I. - Infectivity and distribution of Echinostoma trivolvis in $\mathrm{C} 3 \mathrm{H}$ mice untreated or treated for 5 or 7 days with dexamethasone; each mouse exposed to 40 metacercarial cysts.

100-200 eggs/uterus in contrast to the immature juveniles from the control mice.

\section{GOBLET CELL NUMBER}

Kinetic changes in the number of goblet cells/VCU at the anterior section of the ileum are shown in Fig. 1. The number of goblet cells in the untreated control mice infected with E. trivolvis increased rapidly, reached a peak of $20.6 \pm 0.5$ on day 12 p. i., and then declined. The number of goblet cells in the DEXtreated mice increased slightly on days 8 and 12 p.i., but rapidly increased to $17.2 \pm 0.4$ on day 15 p. i., and reached a peak of $19.8 \pm 0.7$ on day 20 p. i.; beyond that time the number of goblet cells declined gradually.

\section{MAST CELL NUMBER}

Kinetic changes in the number of mucosal mast cells/VCU are shown in Fig. 2. The number of mast cells in the untreated control mice increased rapidly to reach a peak of $11.1 \pm 0.5$ on day 15 p. i., and then declined to $1.0 \pm 0.1$ on day $30 \mathrm{p}$. i. The number of mast cells in the DEX-treated mice increased slowly by day 12 , increased rapidly to reach a peak of $9.7 \pm 0.5$ on day 15 p. i., and then declined to $0.9 \pm 0.2$ on day 30 p. i.

\section{EOSINOPHIL NUMBER}

Kinetic changes in the number of eosinophils/VCU are shown in Fig. 3. The number of eosinophils in the untreated control mice increased rapidly to reach a peak of $23.1 \pm 1.6$ on day 12 p. i. and then declined gradually. The number of eosinophils in the DEX-

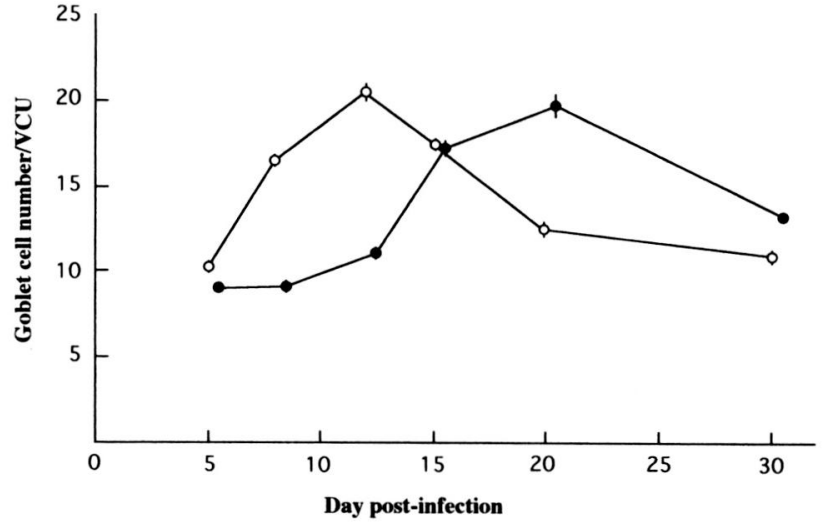

Fig. 1. - Goblet cell number $(x \pm S E)$ VCU of the anterior section of ileum of the intestine of the control (- - ) and dexamethasonetreated (-) mice, which were both infected with Echinostoma trivolvis.

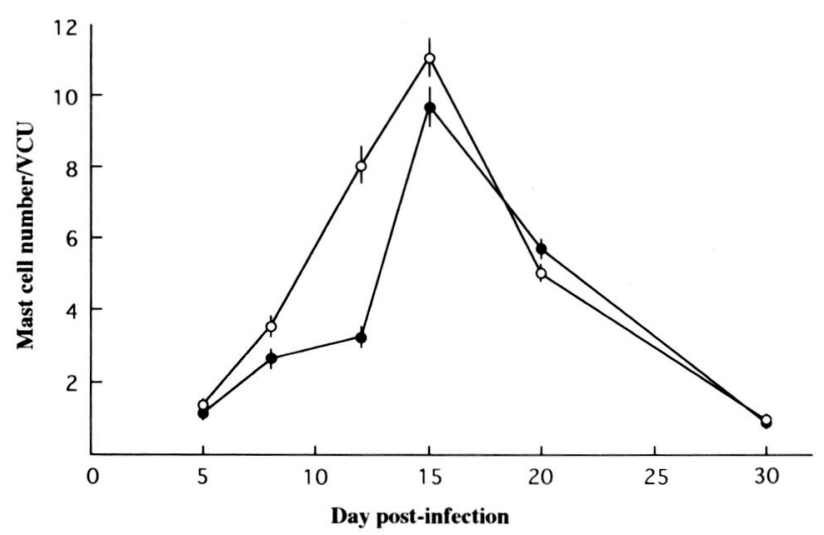

Fig. 2. - Mast cell number $(x \pm \mathrm{SE}) / \mathrm{VCU}$ of the anterior section of ileum of the intestine of the control (-O-) and dexamethasonetreated (-) mice, which were both infected with Echinostoma trivolvis. 


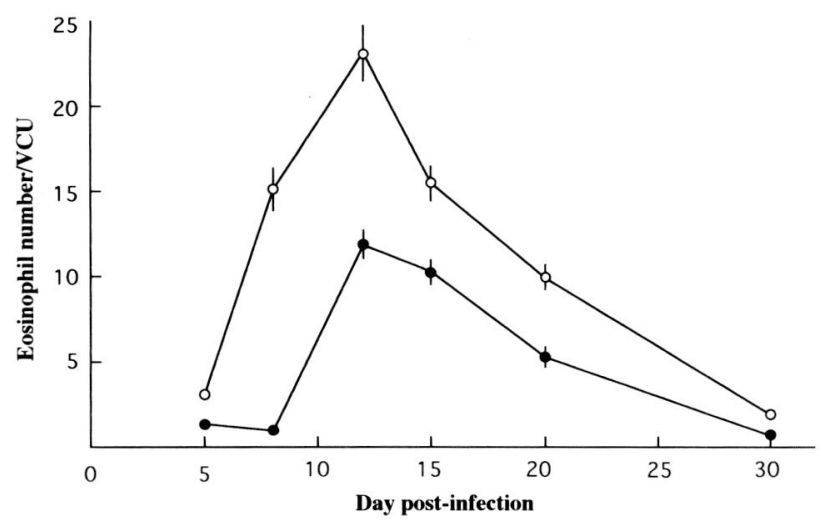

Fig. 3. - Eosinophil number $(x \pm \mathrm{SE}) / \mathrm{VCU}$ of the anterior section of ileum of the intestine of the control (-O-) and dexamethasonetreated (-) mice, which were both infected with Echinostoma trivolvis.

treated mice did not increase until day 8 p. i. and then increased rapidly to reach a peak of $11.8 \pm 0.8$ on day 12 p. i. and then declined gradually.

\section{INTESTINAL HISTOLOGY AND HISTOCHEMISTRY}

In the control mice infected with E. trivolvis, examined on day 12 p. i., the intestinal villi were short with truncate or irregularly wavy distal and lateral margins (Fig. 4A). Goblet cells stained heavily with ABPAS and showed a marked increase in number. Some of the crypt cells stained blue-purple, though most goblet cells and crypt cells stained red-purple. The crypts were oval with an increased number of vacuolate granules in the Paneth cells (Figs. 5A and 5B). Hypertrophy of the tunica muscularis was seen. In the DEX-treated mice, examined on day 12 p. i., the histological features of the intestine in general were similar to those of the control mice (Fig. 4B). The villi were elongate and their distal ends were round or truncated with smooth surfaces. The number of goblet cells was apparently fewer than that of the controls. The crypts, whose cells stained blue-purple, were elongate or oval (Fig. 5C). Most Paneth cells were small with undeveloped tiny granules (Fig. 5D). The tunica muscularis was thin.

\section{TRANSMISSION ELECTRON MICROSCOPY}

There were no marked ultrastructural differences between the intestinal epithelial cells from the untreated control and DEX-treated mice. Amorphous and autophagic vacuoles in the cytoplasm of Paneth cells and multivesicular bodies and vesicles in the apical epithelium were greater in number in the DEX-treated mice than in the controls (Fig. 5E). In some epithelial cells of the DEX-treated mice mitochondria in the apical region contained a greater number of intracristal granules than those of the controls (Fig. 5F).

\section{DISCUSSION}

I $\mathrm{n}$ the present study, DEX-treatment daily for five or seven days suppressed the goblet cell hyperplasia in the small intestine and also delayed the rejection of Echinostoma trivolvis from $\mathrm{C} 3 \mathrm{H}$ mice. The increase in the number of goblet cells was suppressed during the period of DEX-injection, but the goblet cell number began to increase just after the last injection, with the pattern of the cell number similar to that of the initial phase seen in the untreated control. This means that goblet cell hyperplasia is reversible when

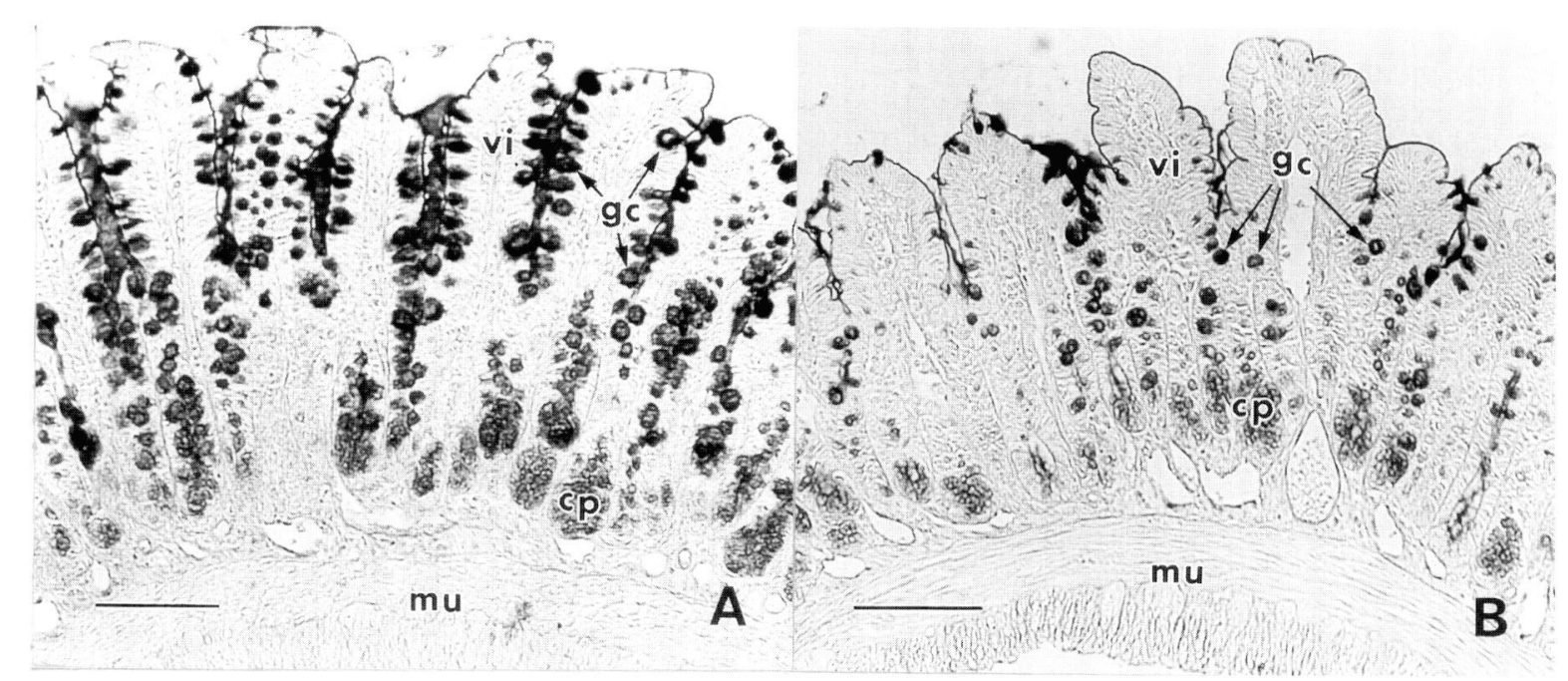

Fig. 4. - Light microscopy of a cross-section of the small intestine of the control and dexamethasone-treated mice on day 12 p.i., stained with alcian-blue-PAS. A : Control mouse intestine. Note increased number of swollen goblet cells (gc). Bar $=100 \mu \mathrm{m}$. B : Dexamethasonetreated mouse intestine. Note no marked increase in the number of goblet cells. Bar $=100 \mu \mathrm{m} . \mathrm{cp}$, crypt; mu, tunica muscularis; vi, villus 

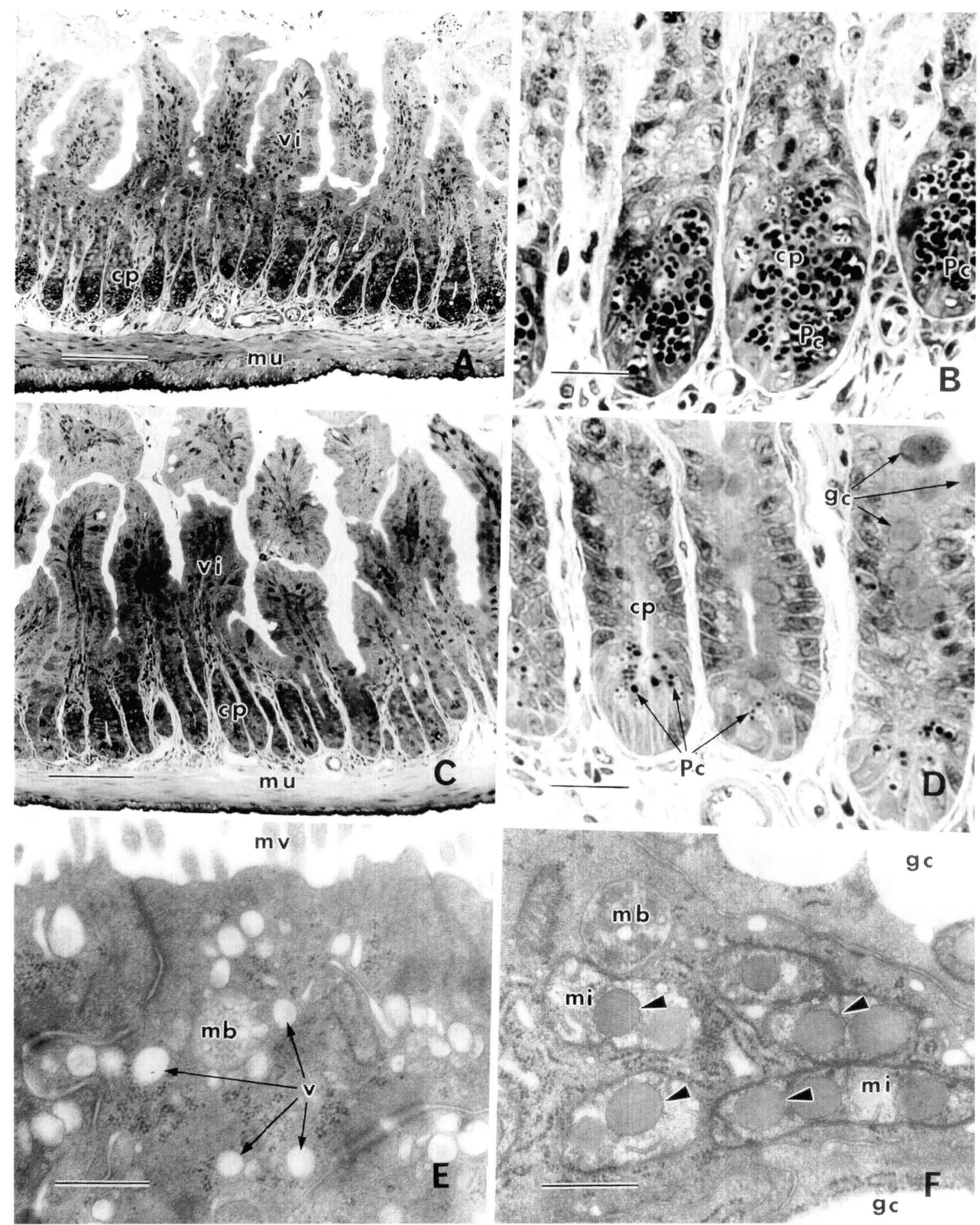

Fig. 5. - The small intestines of the untreated control and dexamethasone-treated mice, examined on day 12 p. i. A : Cross section of control mouse intestine. cp, crypt; mu, tunica muscularis; vi, villus. Bar $=100 \mu \mathrm{m}$. B : Crypts of the control mouse villus. Crypts (cp) are oval with the increased number of Paneth cells (Pc) including mature granules. Bar $=20 \mu \mathrm{m}$. C : Cross section of dexamethasone-treated mouse intestine. $\mathrm{cp}$, crypt; mu, tunica muscularis; vi, villus. Bar $=100 \mu \mathrm{m}$. D : Crypts of the dexamethasone-treated mouse villus. Crypts (cp) are normal, elongate with a few Paneth cells (Pc) including small immature granules. gc, goblet cell. Bar $=20 \mu \mathrm{m}$ E. TEM of the apical epithelium of dexamethasone-treated mouse intestine, showing numerous vesicles (v) and multivesicular body (mb); mv, microvillus. Bar = $0.5 \mu \mathrm{m} \mathrm{F}$. TEM of the apical epithelium of dexamethasone-treated mouse intestine, showing mitochondria (mi) with intracristal granule(s) (arrowheads), gc, goblet cell granule; mb, multivesicular body. Bar $=0.5 \mu \mathrm{m}$. 
DEX-treatment is stopped. The rejection of the worms occurred gradually after DEX-injections in association with the increase in the number of goblet cells, and worm recoveries fell rapidly to zero by day $20 \mathrm{p}$. i. when the number of goblet cells peaked. These findings support the suggestion of Weinstein and Fried (1991) and Fujino et al. (1993) that the expulsion of E. trivolvis from mouse hosts is associated mainly with goblet cell hyperplasia.

Mucosal mast cell number in the intestinal epithelium of the DEX-treated mice in our study was suppressed slightly but the fluctuation pattern of the cell number was similar to that of the control mice, reaching a peak on day 15 p. i. Fujino et al. (1993) studied worm kinetics in conventional and congenitally athymic BALB/C mice infected with $E$. trivolvis and concluded that mast cells are not involved in the worm expulsion of E. trivolvis in mice.

Eosinophil number in the intestinal epithelium of the DEX-treated mice had also been suppressed during the DEX-injection in the present study. This finding suggests that DEX-treatment suppressed T-cell mediated induction or development of eosinophils. It is not clear if increased eosinophils are concerned with the expulsion of the worms. McMaster et al. (1995) examined the effect of DEX on the course of E. trivolvis or E. caproni infection in the golden hamster and noted that the recovery of the worms was increased in association with the fact that white blood cell counts and relative spleen weight were decreased as the result of high doses of DEX. They also noted that increased infectivity seen in DEX-treated hamsters may be the result of the decreased inflammatory response and that corticosteroid treatment resulted in a reduction in the size and number of lymphatic nodules in the small intestine.

Rats treated daily with prednisolone suppressed the initiation of acquired resistance to Nippostrongylus brasiliensis, and the worm expulsion was inhibited completely (Ogilvie, 1965). Ishikawa (1994) also noted that DEX-treatment of mice daily for seven days caused significant suppression of goblet cell hyperplasia in $N$. brasiliensis infection. Mast cells, eosinophils and globule leucocytes, which are commonly found in helminth-infected animals, were strongly affected by cortisone (Asboe-Hansen, 1958; Kent et al., 1954). Both worm expulsion and goblet cell hyperplasia can be adoptively transferred by immunized rat $\mathrm{T}$ cells (Miller \& Nawa, 1979). Nawa et al. (1994) noted that goblet cell changes during expulsion of $N$. brasiliensis can be divided into $\mathrm{T}$ cell-dependent proliferation and $\mathrm{T}$ cellindependent alterations of the terminal sugars of mucins.

In histological examinations, Paneth cells of the crypts in the control mice were well developed with nume- rous vacuolate granules as reported in Fujino and Fried (1993), whereas those in the DEX-treated mice were small with tiny granules. These findings suggest that DEX-treatment suppressed the development of Paneth cells as well as goblet cell hyperplasia.

The effects of cortisone acetate on organ and body weight and $\gamma$-globulin levels were studied in some animals (Shewell \& Long, 1956). Frenkel \& Havenhill (1963) examined the effects of cortisone and of cortisol on golden hamsters. Rhesus monkeys and guinea pigs were characterized as "cortisone resistant", whereas rats, mice, rabbits, ferrets and golden hamsters were "cortisone sensitive" (Shewell \& Long, 1956; Frenkel \& Havenhill, 1963). Sierra-Honigmann \& Murphy (1992) noted that immunosuppression caused by DEX is from activation of $\mathrm{T}$ cell receptor in a manner which appears to involve an early cytokine-regulated signalling pathway. Kunicka et al. (1993) also indicated that administration of a single dose of DEX $(30 \mathrm{mg} / \mathrm{kg})$ in mice results in significant suppression of lymphokine production and cell proliferation. It therefore is possible that several cytokines such as IL-1 (Cohan et al., 1991) and tumor necrosis factor (Jarry et al., 1992) that are known to have regulatory effects on mucosal epithelial cells including goblet cells: induction of mucus secretion of goblet cells or indirect stimulation of some other cells to activate goblet cells, were suppressed by DEX and this delayed the rejection of E. trivolvis from $\mathrm{C} 3 \mathrm{H}$ mice in the present study.

The size of the worms in the DEX-treated mice on day 12 p. i., was significantly larger than that of the controls. This finding differs from the results given by McMaster et al. (1995) in E. trivolvis infection in the golden hamster. They found that dry weights of the echinostomes from DEX-treated hamsters were less than those from the controls. This discrepancy may be due to the difference in the host animals, but merits further study. Most of the worms recovered from the DEX-treated mice on day 12 p. i. were gravid adults in contrast to immature juveniles from the control mice. This finding is useful for raising gravid worms in immunologically suppressed mice to run the life cycle of E. trivolvis in the laboratory-reared Helisoma trivolvis snails (see review in Huffman \& Fried, 1990).

\section{REFERENCES}

Abe T., Khan W.I., Sugaya H., Ishida K. \& Yoshimura K. Prolongation of infection time and failure of restoring fecundity of mouse-nonadaptive Nippostrongylus brasiliensis by administrations of cyclophosphamide or anti-CD 4 antibody in mice. Japanese Journal of Parasitology, 1994, 43, 288293.

Asboe-Hansen G. Hormonal effects on connective tissue. Physiological Review, 1958, 38, 446-462. 
Christensen N.Ø., Fried B. \& Kanev I. Taxonomy of 37-collar spined Echinostoma (Trematoda: Echinostomatidae) in studies on the population regulation in experimental rodent hosts. Angewandte Parasitologie, 1990, 31, 127-130.

Christensen N.Ø., Knudsen J. \& Andreassen J. Echinostoma revolutum: resistance to secondary and superimposed infections in mice. Experimental Parasitology, 1986, 61, 311-318.

Cohan V.L., Scott A.L., Dinarello C.A. \& Prendergast R.A. Interleukin-1 is a mucus secretagogue. Cellular Immuno$\log y, 1991,136,425-434$

Frenkel J.K. \& Havenhill M.A. The corticoid sensitivity of golden hamsters, rats and mice: Effects of dose, time and route of administration. Laboratory Investigation, 1963, 12, 1204-1220.

FujINO T. \& FRIED B. Expulsion of Echinostoma trivolvis (Cort, 1914) Kanev, 1985 and retention of E. caproni Richard, 1964 (Trematoda: Echinostomatidae) in C3H mice: pathological, ultrastructural, and cytochemical effects on the host intestine. Parasitology Research, 1993, 79, 286292.

Fujino T., Fried B. \& Tada I. The expulsion of Echinostoma trivolvis: worm kinetics and intestinal cytopathology in conventional and congenitally athymic BALB/c mice. Parasitology, 1993, 106, 297-304.

Hosier D.W. \& Fried B. Infectivity, growth, and distribution of Echinostoma revolutum in Swiss Webster and ICR mice. Proceedings of the Helminthological Society of Washington, 1986, 53, 173-176.

Huffman J.E. \& Fried B. Echinostoma and echinostomiasis Advances in Parasitology, 1990, 29, 215-269.

ISHIKAWA N. Histochemical characteristics of the goblet cell mucins and their role in defence mechanisms against Nippostrongylus brasiliensis infection in the small intestine of mice. Parasite Immunology, 1994, 16, 649-654.

Ishikawa N., Horit Y., Oinuma T., Suganuma T. \& Nawa Y. Goblet cell mucins as the selective barrier for the intestinal helminths: T-cell-independent alteration of goblet cell mucins by immunologically " damaged "Nippostrongylus brasiliensis worms and its significance on the challenge infection with homologous and heterologous parasites. Immunology, 1994, 81, 480-486.

Jarry A., Muzeau F. \& Laboisse C. Cytokine effects in a human colonic goblet cell line: Cellular damage and its partial prevention by 5 -aminosalicylic acid. Digestive Diseases and Sciences, 1992, 37, 1170-1178.

Kent J.F., Baker B.L., Ingle D.J. \& Li C.H. Effect of corticotropin and cortisone on globule leucocytes of rat. Proceedings of the Society for Experimental Biology and Medicine, 1954, 85, 635-637.

Kunicka J.E., Talle M.A. Denhardt G.H., Brown M. Prince L.A. \& Goldstein G. Immunosuppression by glucocorticoids: Inhibition of production of multiple lymphokines by in vivo administration of dexamethasone. Cellular Immunology, 1993, 149, 39-49.

Konwalinka G., Glaser P., Odavic R., Bogusch E., Schmalzl F. \& Braunsteiner H. A new approach to the morphological and cytochemical evaluation of human bone marrow
CFUc in agar cultures. Experimental Hematology, 1980, 8, 434-440.

Mckay D.M., Halton D.W., McCaigue M.D., Johnston C.F., FAIRWEATHER I. \& SHAW C. Hymenolepis diminuta: intestinal goblet cell response to infection in male $\mathrm{C} 57$ mice. Experimental Parasitology, 1990, 71, 9-20.

Mcmaster R.P., Huffman J.E. \& Fried B. The effect of dexamethasone on the course of Echinostoma caproni and E. trivolvis infections in the golden hamster (Mesocricetus auratus). Parasitology Research, 1995, 81, 518-521.

Miller H.R.P. \& JARRET W.F.H. Immune reactions in mucous membranes: 1. Intestinal mast cell response during helminth expulsion in the rat. Immunology, 1971, 20, 277 288.

Miller H.R.P. \& Nawa Y. Nippostrongylus brasiliensis: intestinal goblet-cell response in adoptively immunized rats. Experimental Parasitology, 1979, 47, 81-90.

Nawa Y., Ishikawa N., Tsuchiya K., Horil Y., Abe T., Khan A.I., Bing-Shi, ITOH H., IDE H. \& Uchiyama F. Selective effector mechanisms for the expulsion of intestinal helminths. Parasite Immunology, 1994, 16, 333-338.

OGILVIE B.M. Use of cortisone derivatives to inhibit resistance to Nippostrongylus brasiliensis and to study the fate of parasites in resistant hosts. Parasitology, 1965, 55, 723-730.

SHewell J. \& Long D.A. A species difference with regard to the effect of cortisone acetate on body weight, $\gamma$-globulin and circulating antitoxin levels. Journal of Hygiene, 1956, 54, 452-460.

Sierra-Honigmann M.R. \& Murphy P.A. T cell receptor-independent immunosuppression induced by dexamethasone in murine T helper cells. Journal of Clinical Investigation, 1992, 89, 556-560.

Weinstein M.S. \& Fried B. The expulsion of Echinostoma trivolvis and retention of Echinostoma caproni in the ICR mouse: pathological effects. International Journal for Parasitology, 1991, 21, 255-257.

Reçu le 18 décembre 1995 Accepté le 4 avril 1996 